\title{
Vertical Distribution Patterns of Element Concentrations in Podetia of Cladonia rangiferina from Huzhong Natural Reserve, Heilongjiang, China
}

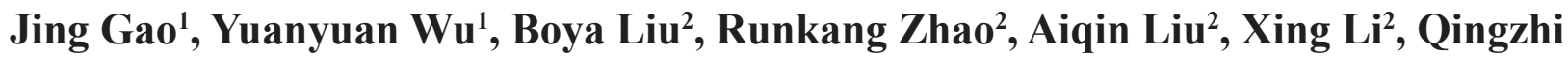 \\ Chen², Lianwei Sun², Xiuping Guo ${ }^{2 *}$, Huajie Liu ${ }^{1 * *}$ \\ ${ }^{1}$ College of Life Sciences, Institute of Life Science and Green development, Hebei University, \\ Baoding, Hebei Province, China \\ ${ }^{2}$ Hebei Research Center for Geoanalysis, Baoding, Hebei Province, China
}

Received: 15 December 2019

Accepted: 24 February 2020

\begin{abstract}
Lichen element compositions are of a reliable tool for the biomonitoring of atmospheric element deposition. The zoning and patterned accumulation of elements in lichen thallus is one of the important factors influencing lichen element concentrations. We collected an epigenous fruticose lichen Cladonia rangiferina $(C R)$ from a remote site of Huzhong National Natural Reserve, Heilongjiang, NE China. Fifty-five elements (Ag, Al, As, B, Ba, Be, Bi, Ca, Cd, Ce, Co, Cr, Cs, Cu, Dy, Er, Eu, Fe, Gd, Ge, Hg, Ho, K, La, Li, Lu, Mg, Mn, Mo, Na, Nb, Nd, Ni, P, Pb, Pr, Rb, S, Sb, Sc, Se, Si, Sm, Sn, Sr, Tb, Th, Ti, $\mathrm{Tl}$, Tm, U, V, Y, Yb, and $\mathrm{Zn}$ ) were measured with their differences among 3 parts (upper, middle, and lower) of the podetia compared. The aim of the present study was to examine the vertical patterns of element accumulation in $C R$.

The results display a very low degree of atmospheric element deposition in the study site. Concentrations of most elements of limited metabolic significance generally increase from the upper to lower parts, indicating a continuous bioaccumulation of these elements with exposure time. Concentrations of some nutrients have little vertical difference among parts ( $\mathrm{Zn}$ ), and they are higher in the upper part than in the middle part $(\mathrm{K}, \mathrm{P}$, and $\mathrm{S})$, or are similar between the upper and middle parts $(\mathrm{B}, \mathrm{Cu}$ and $\mathrm{Mg}$ ). These results suggest a nutrient translocation to the more biologically active young part. Our results highlight the importance of selecting the suitable parts of lichen thallus to increase the comparability of data in lichen biomonitoring studies.
\end{abstract}

Keywords: Cladonia, element composition, bioaccumulation, atmospheric deposition, fruticose lichens

\footnotetext{
*e-mail: 316489636@qq.com
}

**e-mail: liuhuajie@foxmail.com 


\section{Introduction}

Lichens have been used as biomonitors of atmospheric element contamination in a wide range of conditions, including urban areas, industrial sites, and natural habitats [1-4]. Due to their poorly developed or lacking roots, lack of protective cuticle and stomata, large surface area/mass ratio and relatively low growth rate, lichens are dependent highly on the atmosphere for nutrients and can absorb atmospheric contaminants at levels exceeding their physiological requirements and well reflect the atmospheric elemental levels [4, 5]. However, besides atmospheric element concentrations, other factors can also affect element contents in lichen thallus, such as environmental factors (including climate, landscape, vegetation, and type of substrate), lichen species, lichen morphology and eco-physiology [1, 2, 6-10].

The zoning and patterned accumulation of elements in lichen thallus is an important factor influencing lichen element compositions [2, 7, 8]. Some authors observed different element contents along cross section of certain lichen tissues, suggesting an elementspecific internal translocation in lichen thallus [11-13]. Other authors observed element-specific partitioning between old and young parts. Compared with the older parts, the younger ones of lichen thallus are less particle-contaminated and more metabolically active, therefore accumulating a larger amount of nutritional elements [14-16] due to the translocation of these elements in thallus [17]. In contrast, the older parts often accumulate more elements with limited metabolic significance due to the longer exposure time [5, 16, 18]. Some researchers also observed an increasing element concentration with the thallus size of Evernia prunastri [8].

A fully understanding of element distribution patterns in different parts of lichen thallus is a crucial issue associated with lichen biomonitoring technique, in which it is required for the selection of appropriate lichen parts to consider the bioaccumulation capability of atmospheric elements and the comparability of results [19]. The relevant studies have been conducted on epiphytic foliose lichens $[5,18,20]$, epiphytic fruticose lichens [16], and epigenous fruticose lichens $[14,15,21,22]$. However, a limited number of elements $(<20)$ were involved in the abovementioned studies, but such studies have not been conducted in China.

We collected Cladonia rangiferina $(C R)$ in a remote area and compared concentration differences of 55 elements (Ag, Al, As, B, Ba, Be, Bi, Ca, Cd, Ce, Co, $\mathrm{Cr}, \mathrm{Cs}, \mathrm{Cu}, \mathrm{Dy}, \mathrm{Er}, \mathrm{Eu}, \mathrm{Fe}, \mathrm{Gd}, \mathrm{Ge}, \mathrm{Hg}, \mathrm{Ho}, \mathrm{K}, \mathrm{La}$, $\mathrm{Li}, \mathrm{Lu}, \mathrm{Mg}, \mathrm{Mn}, \mathrm{Mo}, \mathrm{Na}, \mathrm{Nb}, \mathrm{Nd}, \mathrm{Ni}, \mathrm{P}, \mathrm{Pb}, \mathrm{Pr}, \mathrm{Rb}$, $\mathrm{S}, \mathrm{Sb}, \mathrm{Sc}, \mathrm{Se}, \mathrm{Si}, \mathrm{Sm}, \mathrm{Sn}, \mathrm{Sr}, \mathrm{Tb}, \mathrm{Th}, \mathrm{Ti}, \mathrm{Tl}, \mathrm{Tm}, \mathrm{U}$, $\mathrm{V}, \mathrm{Y}, \mathrm{Yb}$, and $\mathrm{Zn}$ ) among the upper, middle and lower parts of the secondary thalli (podetia). Our aim was to test the hypothesis that the nutritional elements could be accumulated greater in the upper parts than in the middle/lower parts, with the inverse occurring for the elements with less metabolic significance. This research is the first attempt to explore the distribution patterns of elements in different parts of lichens in China, and to the best of our knowledge, it is one of the lichen biomonitoring studies involving the largest number of elements.

\section{Materials and Methods}

\section{Sample Collection}

Huzhong National Natural Reserve (51 ${ }^{\circ} 17^{\prime}-51^{\circ} 56^{\prime} \mathrm{N}$, $\left.122^{\circ} 42^{\prime}-123^{\circ} 18^{\prime} \mathrm{E}\right)$ locates in the Greater Khingan Mountains of Heilongjiang, NE China (Fig. 1a). The climate is of cold temperate continental monsoon, with a mean annual precipitation of $497.7 \mathrm{~mm}$ and a mean annual temperature of $-4.4^{\circ} \mathrm{C}$. The vegetation is typical coniferous forest ecosystem with abundant lichens. There was no obvious industrial, agricultural, mining and transport activity in the Reserve with the nearest town approximately $40 \mathrm{~km}$ away from the sampling site (Fig. 1b).

In August 8, 2017>100 thalli of a fruticose lichen $C R$ were randomly collected by hand, sealed in clean paper bags, immediately transported to the laboratory, air-dried and maintained at room temperature till used. All samples were collected in an area of $100 \times 100 \mathrm{~m}^{2}$ with similar geomorphological and landscape characteristics in a rural site $\left(51^{\circ} 47^{\prime} 03^{\prime}\right.$ ' $\mathrm{N}$, $\left.123^{\circ} 00^{\prime} 48^{\prime \prime} \mathrm{E}\right)$. The site is flat with an elevation of $773 \mathrm{~m}$. The predominant ecosystem is boreal coniferous forest dominated by Larix gmelinii (Rupr.) Kuzen. The undergrowth shrubs are dominated by Ledum palustre L., Vaccinium vitis-idaea L., Rhododendron dauricum L. and Alnus mandshurica (Callier ex C. K. Schneider) Handel-Mazzetti (Fig. 1c). $C R$ was chosen because it is abundant and often forms a carpet on the ground among shrubs (Fig. 1c) in the region, and it was studied in the biomonitoring research in Arctic [23], Norway [24], Russia [25-27], Japan [28], and Canada [29]. The collection area was restricted to $10,000 \mathrm{~m}^{2}$ to minimize the potential effects of local microhabitat variations on the lichen element composition. Indeed, the UNECE ICP-vegetation (International Cooperative Program on Effects of Air Pollution on Natural Vegetation and Crops) protocol recommended that moss samples for moss biomonitoring studies should be collected in an area of $50 \times 50 \mathrm{~m}^{2}$ in each site [30]. In lichen biomonitoring studies, epigenous lichens were also collected in an area of approximately $50 \times 50 \mathrm{~m}^{2}$ for Cladonia rangiformis [31].

\section{Sample Preparation and Measurement}

$C R$ samples were carefully cleaned with plastic tweezers by a low magnification stereomicroscope. Parts of the podetia in intimate contact with soil were removed to minimize possible soil contamination of 


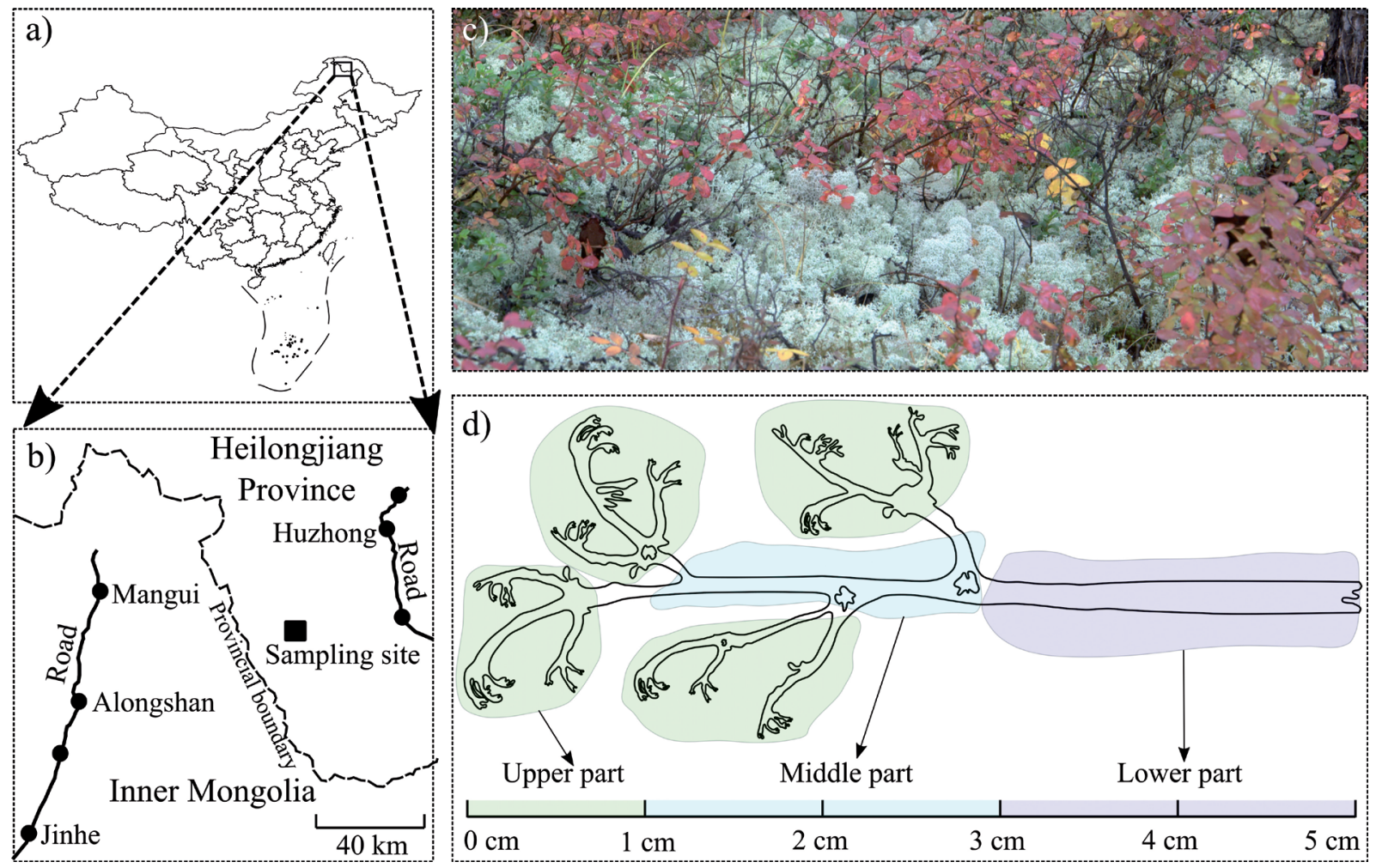

Fig. 1. Sampling site, habitat and Cladonia rangiferina: a) location of the Huzhong National Natural Reserve; b) location of sampling site (the solid circles indicate towns, and the block indicates the sampling site); c) habitat of $C R$ (the gray-white carpet on ground); d) parts of a podetium.

samples. Podetia of approximately $5 \mathrm{~cm}$ in height were selected and randomly assigned to 6 replicates. Each replicate contained 8-12 podetia; each podetium was cut into three parts with a plastic blade (upper: $0-1 \mathrm{~cm}$ from the top of podetia; middle: $1-3 \mathrm{~cm}$; and lower: $3-5 \mathrm{~cm}$. Fig. 1d). A total of 18 samples ( 6 replicates $\times 3$ parts) were dried to a constant weight at $70^{\circ} \mathrm{C}$ for $72 \mathrm{~h}$ in a drying oven, and were then ground and homogenized in a grinding mill equipped with Tungsten Carbide jars (Retsch MM400; Retsch GmbH, Haan, Germany).

A 200-300 $\mathrm{mg}$ sample was mineralized by microwaves with $\mathrm{HNO}_{3}$ and $\mathrm{H}_{2} \mathrm{O}_{2}$. Concentrations of 55 elements ( $\mathrm{Ag}, \mathrm{Al}, \mathrm{As}, \mathrm{B}, \mathrm{Ba}, \mathrm{Be}, \mathrm{Bi}, \mathrm{Ca}, \mathrm{Cd}, \mathrm{Ce}, \mathrm{Co}$, $\mathrm{Cr}, \mathrm{Cs}, \mathrm{Cu}, \mathrm{Dy}, \mathrm{Er}, \mathrm{Eu}, \mathrm{Fe}, \mathrm{Gd}, \mathrm{Ge}, \mathrm{Hg}, \mathrm{Ho}, \mathrm{K}, \mathrm{La}, \mathrm{Li}$, $\mathrm{Lu}, \mathrm{Mg}, \mathrm{Mn}, \mathrm{Mo}, \mathrm{Na}, \mathrm{Nb}, \mathrm{Nd}, \mathrm{Ni}, \mathrm{P}, \mathrm{Pb}, \mathrm{Pr}, \mathrm{Rb}, \mathrm{S}, \mathrm{Sb}$, Sc, Se, Si, Sm, Sn, Sr, Tb, Th, Ti, Tl, Tm, U, V, Y, Yb, and $\mathrm{Zn}$ ) were determined using an inductively coupled plasma mass spectrometer (ICP-MS; Agilent 7700X; Agilent Technologies, Tokyo, Japan) at the Hebei Research Center for Geoanalysis.

The analytical quality of the ICP-MS results was checked against the following standard reference materials: GBW10014 (cabbage), GBW10015 (spinach), GBW10052 (green tea) provided by the Institute of Geophysical and Geochemical Exploration, Chinese Academy of Geological Sciences; IAEA-336 (Portuguese lichen) was from the International Atomic Energy Agency. The analytical precision and accuracy were within $10 \%$ with the detection limits being generally of $<0.001 \mu \mathrm{g} / \mathrm{ml}$ for all elements.

\section{Statistical Analyses}

A Shapiro-Wilk test was performed to test the normality of data distribution of element concentrations. It was normal for all elements in each part, except $\mathrm{Bi}$ in the middle part and $\mathrm{B}$ and $\mathrm{Mn}$ in the lower part. The significance of concentration differences among parts was tested using a pairedsamples $\mathrm{t}$ test with a Bonferroni correction for multicomparisons. In this analysis, concentrations of 12 elements were lg-transformed (B, Dy, Lu, Mn, $\mathrm{Na}, \mathrm{Sb}, \mathrm{Sn}, \mathrm{Sr}, \mathrm{Ti}$, and $\mathrm{U}$ ) or cubic root-transformed (Ba and $\mathrm{Hg}$ ) to increase the normality of concentration differences between every two parts. All analyses were conducted using the software PAST 3.25 (Ø. Hammer, April 2019).

\section{Results}

Table 1 shows the concentration values of 55 elements in three parts of $C R$. All elements show only a little to small concentration variations (CV: 4.0$25.0 \%$ ), except B in the upper (CV: 27.7\%) and middle $(\mathrm{CV}=28.0 \%)$ parts and 5 elements $(\mathrm{Ag}, \mathrm{B}, \mathrm{Cd}, \mathrm{Hg}$, and Mn; CV: 25.8-46.7\%) in the lower part. 
Table 1. Element concentrations in three parts of Cladonia rangiferina.

\begin{tabular}{|c|c|c|c|c|c|c|c|c|c|c|c|c|c|}
\hline & \multicolumn{2}{|c|}{$\begin{array}{c}\text { Upper part } \\
\left(\mu \mathrm{g} \mathrm{g}^{-1} ; \mathrm{n}=6\right)\end{array}$} & \multicolumn{2}{|c|}{$\begin{array}{c}\text { Middle part } \\
\left(\mu \mathrm{g} \mathrm{g}^{-1} ; \mathrm{n}=6\right)\end{array}$} & \multicolumn{2}{|c|}{$\begin{array}{c}\text { Lower part } \\
\left(\mu \mathrm{g} \mathrm{g}^{-1} ; \mathrm{n}=6\right)\end{array}$} & & \multicolumn{2}{|c|}{$\begin{array}{c}\text { Upper part } \\
\left(\mu \mathrm{g} \mathrm{g}^{-1} ; \mathrm{n}=6\right)\end{array}$} & \multicolumn{2}{|c|}{$\begin{array}{c}\text { Middle part } \\
\left(\mu \mathrm{g} \mathrm{g}^{-1} ; \mathrm{n}=6\right)\end{array}$} & \multicolumn{2}{|c|}{$\begin{array}{c}\text { Lower part } \\
\left(\mu \mathrm{g} \mathrm{g}^{-1} ; \mathrm{n}=6\right)\end{array}$} \\
\hline & Mean & $\mathrm{CV}(\%)$ & Mean & $\mathrm{CV}(\%)$ & Mean & $\mathrm{CV}(\%)$ & & Mean & CV(\%) & Mean & $\mathrm{CV}(\%)$ & Mean & $\mathrm{CV}(\%)$ \\
\hline $\mathrm{Ag}$ & 0.015 & 13.33 & 0.037 & 13.51 & 0.031 & 25.81 & Mo & 0.050 & 12.00 & 0.096 & 12.5 & 0.216 & 17.59 \\
\hline $\mathrm{Al}$ & 781.9 & 13.07 & 1402 & 7.30 & 6739 & 16.13 & $\mathrm{Na}$ & 124.7 & 13.97 & 269.3 & 11.24 & 943.3 & 13.04 \\
\hline As & 0.300 & 9.33 & 0.402 & 8.21 & 0.758 & 14.25 & $\mathrm{Nb}$ & 0.078 & 20.51 & 0.173 & 11.56 & 0.487 & 21.77 \\
\hline B & 2.897 & 27.68 & 2.953 & 27.97 & 4.368 & 46.66 & $\mathrm{Nd}$ & 0.356 & 12.64 & 0.667 & 6.90 & 2.277 & 15.33 \\
\hline $\mathrm{Ba}$ & 16.36 & 7.42 & 25.44 & 4.66 & 62.86 & 17.64 & $\mathrm{Ni}$ & 0.463 & 5.83 & 0.662 & 6.80 & 1.790 & 18.66 \\
\hline $\mathrm{Be}$ & 0.018 & 16.67 & 0.037 & 8.11 & 0.129 & 10.08 & $\mathrm{P}$ & 1201 & 8.93 & 720.6 & 4.57 & 671.7 & 14.75 \\
\hline $\mathrm{Bi}$ & 0.016 & 12.50 & 0.022 & 9.09 & 0.058 & 18.97 & $\mathrm{~Pb}$ & 0.695 & 15.83 & 0.966 & 9.32 & 2.579 & 21.36 \\
\hline $\mathrm{Ca}$ & 991.8 & 7.36 & 1231 & 5.27 & 1999 & 12.58 & $\operatorname{Pr}$ & 0.090 & 15.56 & 0.178 & 13.48 & 0.576 & 13.89 \\
\hline $\mathrm{Cd}$ & 0.035 & 5.71 & 0.059 & 8.47 & 0.053 & 26.42 & $\mathrm{Rb}$ & 4.016 & 9.44 & 4.886 & 6.24 & 12.32 & 16.24 \\
\hline $\mathrm{Ce}$ & 0.785 & 11.08 & 1.523 & 8.14 & 5.051 & 15.66 & $\mathrm{~S}$ & 625.9 & 9.22 & 396.5 & 7.17 & 460.3 & 16.31 \\
\hline Co & 0.163 & 14.11 & 0.239 & 12.55 & 0.738 & 19.51 & $\mathrm{Sb}$ & 0.029 & 6.90 & 0.038 & 7.89 & 0.074 & 22.97 \\
\hline $\mathrm{Cr}$ & 0.644 & 17.55 & 1.180 & 9.32 & 3.694 & 17.03 & $\mathrm{Sc}$ & 0.098 & 16.33 & 0.196 & 11.22 & 0.656 & 17.99 \\
\hline Cs & 0.142 & 14.79 & 0.250 & 9.20 & 0.933 & 17.68 & $\mathrm{Se}$ & 0.063 & 22.22 & 0.082 & 8.54 & 0.219 & 18.72 \\
\hline $\mathrm{Cu}$ & 1.803 & 11.59 & 1.716 & 7.52 & 2.934 & 15.47 & $\mathrm{Si}$ & 1993 & 17.27 & 3825 & 12.06 & 15475 & 10.56 \\
\hline Dy & 0.047 & 12.77 & 0.083 & 8.43 & 0.281 & 16.73 & $\mathrm{Sm}$ & 0.063 & 14.29 & 0.125 & 10.40 & 0.413 & 16.22 \\
\hline $\mathrm{Er}$ & 0.022 & 13.64 & 0.042 & 9.52 & 0.129 & 17.05 & $\mathrm{Sn}$ & 0.051 & 11.76 & 0.080 & 8.75 & 0.222 & 19.82 \\
\hline $\mathrm{Eu}$ & 0.015 & 6.67 & 0.027 & 7.41 & 0.088 & 18.18 & $\mathrm{Sr}$ & 11.54 & 3.99 & 16.30 & 6.30 & 30.49 & 15.89 \\
\hline $\mathrm{Fe}$ & 295.2 & 15.66 & 611.5 & 11.02 & 2101 & 17.28 & $\mathrm{~Tb}$ & 0.0083 & 14.46 & 0.0147 & 11.56 & 0.0478 & 18.41 \\
\hline $\mathrm{Gd}$ & 0.055 & 7.27 & 0.102 & 8.82 & 0.330 & 13.33 & Th & 0.100 & 18.00 & 0.222 & 11.26 & 0.787 & 18.30 \\
\hline $\mathrm{Ge}$ & 0.015 & 13.33 & 0.027 & 7.41 & 0.089 & 17.98 & $\mathrm{Ti}$ & 46.55 & 19.47 & 104.9 & 9.03 & 286.8 & 18.81 \\
\hline $\mathrm{Hg}$ & 0.021 & 9.52 & 0.028 & 10.71 & 0.052 & 28.85 & $\mathrm{Tl}$ & 0.015 & 13.33 & 0.029 & 13.79 & 0.076 & 18.42 \\
\hline Ho & 0.009 & 11.11 & 0.015 & 6.67 & 0.053 & 20.75 & $\mathrm{Tm}$ & 0.0035 & 11.43 & 0.0066 & 9.09 & 0.0209 & 19.62 \\
\hline $\mathrm{K}$ & 2591 & 7.54 & 2032 & 4.89 & 2487 & 13.31 & $\mathrm{U}$ & 0.031 & 12.9 & 0.074 & 9.46 & 0.290 & 19.31 \\
\hline $\mathrm{La}$ & 0.414 & 13.04 & 0.843 & 9.25 & 2.679 & 15.57 & $\mathrm{~V}$ & 0.784 & 17.35 & 1.600 & 10.50 & 5.297 & 16.99 \\
\hline $\mathrm{Li}$ & 0.345 & 20.58 & 0.797 & 14.18 & 2.734 & 16.24 & $\mathrm{Y}$ & 0.218 & 14.22 & 0.391 & 6.14 & 1.301 & 16.76 \\
\hline $\mathrm{Lu}$ & 0.0031 & 16.13 & 0.0059 & 6.78 & 0.0194 & 15.98 & $\mathrm{Yb}$ & 0.022 & 18.18 & 0.039 & 10.26 & 0.135 & 17.04 \\
\hline $\mathrm{Mg}$ & 488.4 & 9.79 & 509.9 & 8.17 & 843.2 & 10.98 & $\mathrm{Zn}$ & 18.16 & 6.86 & 18.96 & 5.02 & 22.18 & 15.37 \\
\hline $\mathrm{Mn}$ & 195.2 & 7.76 & 232.4 & 10.52 & 412.3 & 36.96 & & & & & & & \\
\hline
\end{tabular}

Fig. 2 shows the concentration differences between the three parts. The concentrations for all elements but $\mathrm{Zn}$ are significantly different among the three parts. The concentrations for 46 elements (Al, As, Ba, Be, Bi, Ca, Ce, Co, Cr, Cs, Dy, Er, $\mathrm{Eu}, \mathrm{Fe}, \mathrm{Gd}, \mathrm{Ge}, \mathrm{Hg}$, Ho, La, Li, Lu, Mn, Mo, $\mathrm{Na}, \mathrm{Nb}, \mathrm{Nd}, \mathrm{Ni}, \mathrm{Pb}, \mathrm{Pr}, \mathrm{Rb}, \mathrm{Sb}, \mathrm{Sc}, \mathrm{Se}, \mathrm{Si}, \mathrm{Sm}$, $\mathrm{Sn}, \mathrm{Sr}, \mathrm{Tb}, \mathrm{Th}, \mathrm{Ti}, \mathrm{Tl}, \mathrm{Tm}, \mathrm{U}, \mathrm{V}, \mathrm{Y}$, and $\mathrm{Yb}$ ) increased in the order of upper $<$ middle $<$ lower part (Fig. 2a); they were 2- to 9-fold higher in the lower parts than in the upper part, and were 1.6- to 4.7-fold higher in the lower parts than in the middle part
(Fig. 2b). The concentrations for $\mathrm{Ag}$ and $\mathrm{Cd}$ followed the order of upper $<$ middle $=$ lower part (Fig. 2a); they were 1.5- to 2.1-fold higher in the lower part than those in the upper part (Fig. 2b).

The concentrations of $\mathrm{B}, \mathrm{Cu}$ and $\mathrm{Mg}$ followed the order of upper $=$ middle $<$ lower part (Fig. 2a); they were 1.6-2.1 folds higher in the lower part than in the other parts (Fig. 2b). The concentration of $\mathrm{K}$ followed the order of upper $=$ lower $>$ middle part (Fig. $2 \mathrm{a}$ ), and it was 1.3-fold higher in the upper part than in the middle part (Fig. 2b). The concentrations of $\mathrm{P}$ and $\mathrm{S}$ followed the order of upper $>$ middle $=$ lower part (Fig. 2a), and 
they were 1.4-1.8 folds higher in the upper part than in the lower part (Fig. 2b).

a) Vertical patterns of element concentrations
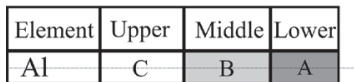

\begin{tabular}{|l|c|c|c|}
\hline $\mathrm{As}$ & $\mathrm{C}$ & $\mathrm{B}$ & $\mathrm{A}$ \\
\hline $\mathrm{Ba}$ & $\mathrm{C}$ & $\mathrm{B}$ & $\mathrm{A}$ \\
\hline
\end{tabular}

\begin{tabular}{|l|c|c|c|}
\hline $\mathrm{Ba}$ & $\mathrm{C}$ & $\mathrm{B}$ & $\mathrm{A}$ \\
\hline $\mathrm{Be}$ & $\mathrm{C}$ & $\mathrm{B}$ & $\mathrm{A}$ \\
\hline $\mathrm{Bi}$ & $\mathrm{C}$ & $\mathrm{B}$ & $\mathrm{A}$ \\
\hline
\end{tabular}

\begin{tabular}{|l|l|l|l|}
\hline $\mathrm{Ba}$ & $\mathrm{C}$ & $\mathrm{B}$ & $\mathrm{A}$ \\
\hline $\mathrm{Ce}$ & $\mathrm{C}$ & $\mathrm{B}$ & $\mathrm{A}$ \\
\hline
\end{tabular}

\begin{tabular}{|l|c|c|c|}
\hline $\mathrm{Ce}$ & $\mathrm{C}$ & $\mathrm{B}$ & $\mathrm{A}$ \\
\hline $\mathrm{Co}$ & $\mathrm{C}$ & $\mathrm{B}$ & $\mathrm{A}$ \\
\hline
\end{tabular}

\begin{tabular}{|c|c|c|c|}
$\mathrm{Co}$ & $\mathrm{C}$ & $\mathrm{B}$ & $\mathrm{A}$ \\
\hline $\mathrm{Cr}$ & $\mathrm{C}$ & $\mathrm{B}$ & $\mathrm{A}$ \\
\hline
\end{tabular}

\begin{tabular}{|l|l|l|l|}
\hline Cs & C & B & A \\
\hline
\end{tabular}

\begin{tabular}{|l|l|l|l|}
\hline Cs & C & B & A \\
\hline Dy & C & B & A \\
\hline
\end{tabular}

\begin{tabular}{|l|c|c|c|}
\hline $\mathrm{Er}$ & $\mathrm{C}$ & $\mathrm{B}$ & $\mathrm{A}$ \\
\hline $\mathrm{Eu}$ & $\mathrm{C}$ & $\mathrm{B}$ & $\mathrm{A}$ \\
\hline
\end{tabular}

\begin{tabular}{|l|l|l|l|}
\hline $\mathrm{Fe}$ & $\mathrm{C}$ & $\mathrm{B}$ & $\mathrm{A}$ \\
\hline
\end{tabular}

\begin{tabular}{|c|c|c|c|}
\hline Gd & C & B & A \\
\hline Ge & C & B & A \\
\hline
\end{tabular}

\begin{tabular}{|l|l|l|l|}
\hline $\mathrm{Hg}$ & $\mathrm{C}$ & $\mathrm{B}$ & $\mathrm{A}$ \\
\hline
\end{tabular}

\begin{tabular}{|l|l|l|l|}
\hline Ho & C & B & A \\
\hline
\end{tabular}

\begin{tabular}{|l|l|l|l}
$\mathrm{La}$ & $\mathrm{C}$ & $\mathrm{B}$ & $\mathrm{A}$ \\
\hline
\end{tabular}

\begin{tabular}{|l|c|c|c|}
\hline $\mathrm{Li}$ & $\mathrm{C}$ & $\mathrm{B}$ & $\mathrm{A}$ \\
\hline $\mathrm{Lu}$ & $\mathrm{C}$ & $\mathrm{B}$ & $\mathrm{A}$ \\
\hline
\end{tabular}

\begin{tabular}{l|l|l|l}
\hline $\mathrm{Mn}$ & $\mathrm{C}$ & $\mathrm{B}$ & $\mathrm{A}$ \\
\hline
\end{tabular}

\begin{tabular}{|l|l|l|l}
\hline Mo & C & B & A \\
\hline
\end{tabular}

\begin{tabular}{|l|l|l|l|}
\hline $\mathrm{Na}$ & $\mathrm{C}$ & $\mathrm{B}$ & $\mathrm{A}$ \\
\hline
\end{tabular}

$\mathrm{Nb}$

\begin{tabular}{l|l|l|l}
$\mathrm{Nd}$ & $\mathrm{C}$ & $\mathrm{B}$ & $\mathrm{A}$ \\
\hline
\end{tabular}

\begin{tabular}{|l|l|l|l|}
\hline $\mathrm{Ni}$ & $\mathrm{C}$ & $\mathrm{B}$ & $\mathrm{A}$ \\
\hline $\mathrm{Pb}$ & $\mathrm{C}$ & $\mathrm{B}$ & $\mathrm{A}$ \\
\hline
\end{tabular}

\begin{tabular}{|c|c|c|c|}
\hline $\mathrm{Pb}$ & $\mathrm{C}$ & $\mathrm{B}$ & $\mathrm{A}$ \\
\hline
\end{tabular}

\begin{tabular}{|l|c|c|c|}
\hline $\mathrm{Pr}$ & $\mathrm{C}$ & $\mathrm{B}$ & $\mathrm{A}$ \\
\hline $\mathrm{Rb}$ & $\mathrm{C}$ & $\mathrm{B}$ & $\mathrm{A}$ \\
\hline
\end{tabular}

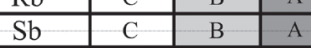

\begin{tabular}{|l|l|l|l|}
\hline $\mathrm{Sb}$ & $\mathrm{C}$ & $\mathrm{B}$ & $\mathrm{A}$ \\
\hline $\mathrm{Se}$ & $\mathrm{C}$ & $\mathrm{B}$ & $\mathrm{A}$ \\
\hline
\end{tabular}

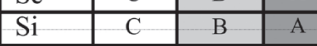

\begin{tabular}{|l|c|c|c|}
\hline $\mathrm{Sm}$ & $\mathrm{C}$ & $\mathrm{B}$ & $\mathrm{A}$ \\
\hline $\mathrm{Sn}$ & $\mathrm{C}$ & $\mathrm{B}$ & $\mathrm{A}$ \\
\hline
\end{tabular}

\begin{tabular}{|l|l|l|l}
\hline Sr & C & B & A \\
\hline
\end{tabular}

\begin{tabular}{|l|l|l|l|}
\hline $\mathrm{Tb}$ & $\mathrm{C}$ & $\mathrm{B}$ & $\mathrm{A}$ \\
\hline
\end{tabular}

\begin{tabular}{|l|l|l|l|}
\hline Th & C & B & A \\
\hline
\end{tabular}

\begin{tabular}{|c|c|c|c|}
\hline $\mathrm{Ti}$ & $\mathrm{C}$ & $\mathrm{B}$ & $\mathrm{A}$ \\
\hline $\mathrm{Tl}$ & $\mathrm{C}$ & $\mathrm{B}$ & $\mathrm{A}$ \\
\hline
\end{tabular}

\begin{tabular}{|l|l|l|l}
\hline $\mathrm{Tm}$ & $\mathrm{C}$ & $\mathrm{B}$ & $\mathrm{A}$ \\
\hline
\end{tabular}

\begin{tabular}{|l|l|l|l|}
\hline $\mathrm{U}$ & $\mathrm{C}$ & $\mathrm{B}$ & $\mathrm{A}$ \\
\hline $\mathrm{V}$ & $\mathrm{C}$ & $\mathrm{B}$ & $\mathrm{A}$ \\
\hline
\end{tabular}

\begin{tabular}{|l|c|c|c|}
\hline $\mathrm{V}$ & $\mathrm{C}$ & $\mathrm{B}$ & $\mathrm{A}$ \\
\hline $\mathrm{Y}$ & $\mathrm{C}$ & $\mathrm{B}$ & $\mathrm{A}$ \\
\hline
\end{tabular}

\begin{tabular}{|c|c|c|c|}
\hline $\mathrm{Yb}$ & $\mathrm{C}$ & $\mathrm{B}$ & $\mathrm{A}$ \\
\hline
\end{tabular}

\begin{tabular}{|c|c|c|c|}
\hline $\mathrm{Ag}$ & $\mathrm{B}$ & $\mathrm{A}$ & $\mathrm{A}$ \\
\hline $\mathrm{Cd}$ & $\mathrm{B}$ & $\mathrm{A}$ & $\mathrm{A}$ \\
\hline
\end{tabular}

\begin{tabular}{|l|c|c|c|}
\hline $\mathrm{Cd}$ & $\mathrm{B}$ & $\mathrm{A}$ & $\mathrm{A}$ \\
\hline $\mathrm{B}$ & $\mathrm{B}$ & $\mathrm{B}$ & $\mathrm{A}$ \\
\hline
\end{tabular}

\begin{tabular}{|l|c|c|c|}
\hline $\mathrm{Bu}$ & $\mathrm{B}$ & $\mathrm{B}$ & $\mathrm{A}$ \\
\hline
\end{tabular}

\begin{tabular}{|l|c|c|c|}
\hline $\mathrm{Mg}$ & $\mathrm{B}$ & $\mathrm{B}$ & $\mathrm{A}$ \\
\hline
\end{tabular}

\begin{tabular}{|l|c|c|c|}
\hline $\mathrm{K}$ & $\mathrm{A}$ & $\mathrm{B}$ & $\mathrm{A}$ \\
\hline
\end{tabular}

\begin{tabular}{|l|c|c|c|}
\hline $\mathrm{P}$ & $\mathrm{A}$ & $\mathrm{B}$ & $\mathrm{B}$ \\
\hline $\mathrm{S}$ & $\mathrm{A}$ & $\mathrm{B}$ & $\mathrm{B}$ \\
\hline
\end{tabular}

\begin{tabular}{|l|c|c|c|}
\hline $\mathrm{S}$ & $\mathrm{A}$ & $\mathrm{B}$ & $\mathrm{B}$ \\
\hline $\mathrm{Zn}$ & $\mathrm{A}$ & $\mathrm{A}$ & $\mathrm{A}$ \\
\hline
\end{tabular}

b) Element concentrations normalized to the lower part 0.00 .20 .40 .60 .81 .01 .21 .41 .61 .8

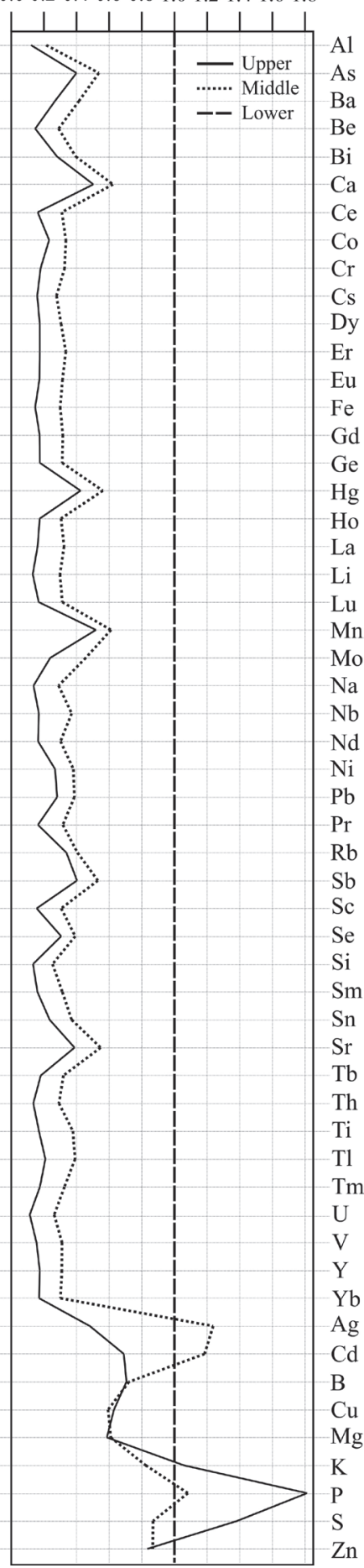

Fig. 2. Element concentration differences among three parts of Cladonia rangiferina: a) vertical patterns of element concentrations (for each element, the different capital letters indicate significant differences among 3 parts; $A>B>C$; pairedsamples $\mathrm{t}$ test with Bonferroni correction; $\mathrm{n}=18$ ); b) element concentrations normalized to the lower part.

\section{Discussion}

\section{Atmospheric Deposition Degree}

Our results show a very low degree of atmospheric deposition in the study site. The concentrations of measured elements in the upper part of $C R$ (Table 1) are within or close to the reported background or baseline concentrations in lichens from the remote sites of Arctic regions [23], Norway, [24], and Turkey [31] (Table 2). This conclusion is also supported by a comparison of our data with those from the other lichen biomonitoring studies conducted in remote sites, such as Usnea subfloridana from Canada [32], severally lichens from the France [33] and Arctic regions [34], Usnea sp. from the forest-grassland regions of Chile [35], Cladonia rangiferina and $C$. stellaris from the remote sites of Russia [24, 27], epiphytic lichens from Italy [10, 3639] and France [40], and several lichens from Inner Mongolia, China [41, 42].

\section{Vertical Distribution of Elements}

All elements but $\mathrm{Zn}$ were significantly different among parts (Fig. 2). Such differences should not be attributed to the effects of local microhabitat variations because a low intra-sample variability in lichen contents were detected for all but a few elements in each part of $C R(\mathrm{CV}<25 \%$; Table 1).

The amount of 49 elements shows an increasing pattern from the upper to lower parts, with a lowest concentration in the upper part and a highest concentration in the lower part for 46 elements (Al, As, $\mathrm{Ba}, \mathrm{Be}, \mathrm{Bi}, \mathrm{Ca}, \mathrm{Ce}, \mathrm{Co}, \mathrm{Cr}, \mathrm{Cs}, \mathrm{Dy}, \mathrm{Er}, \mathrm{Eu}, \mathrm{Fe}, \mathrm{Gd}, \mathrm{Ge}$, $\mathrm{Hg}$, Ho, La, Li, Lu, Mn, Mo, Na, Nb, Nd, Ni, Pb, Pr, Rb, $\mathrm{Sb}, \mathrm{Sc}, \mathrm{Se}, \mathrm{Si}, \mathrm{Sm}, \mathrm{Sn}, \mathrm{Sr}, \mathrm{Tb}, \mathrm{Th}, \mathrm{Ti}, \mathrm{Tl}, \mathrm{Tm}, \mathrm{U}, \mathrm{V}, \mathrm{Y}$, and $\mathrm{Yb}$ ), or a similar concentration between the middle and lower parts for 2 elements (Ag, and $\mathrm{Cd}$ ). Most of these elements are of limited metabolic significance and are rarely bioregulated by lichens. This pattern agrees quite well with other studies. For example, metals with limited metabolic significance ( $\mathrm{Al}, \mathrm{Cd}, \mathrm{Pb}$, and $\mathrm{V}$ ) had higher concentrations in the older parts than in the younger parts of epiphytic foliose lichen Flavoparmelia caperata $[16,18]$. Concentrations of Al were higher in the older parts of epiphytic fruticose lichen Evernia prunastri [16]. $\mathrm{Cr}, \mathrm{Fe}, \mathrm{Na}, \mathrm{Ni}$ and $\mathrm{Pb}$ had higher concentrations in the older parts of Physcia biziana [20]. In some Cladonia lichens, the increasing concentrations from the apex to the base of thalli were observed for $\mathrm{As}, \mathrm{Cd}$, and $\mathrm{Pb}$ [22], $\mathrm{Fe}$ and $\mathrm{Pb}$ [14], and $\mathrm{Al}, \mathrm{Ca}, \mathrm{Cr}$, $\mathrm{Fe}, \mathrm{Si}$, and Ti [26]. Most of the abovementioned studies attributed such patterns to the longer exposure time and higher cation exchange capacity in the older parts and limited translocation of these elements in lichen thallus $[16,17]$. Soil contamination of the lower part is highly unlike an explanation for the higher accumulation of this part because the parts intimately contacted with the soil were removed before chemical analysis. 
Table 2. Comparison of element concentrations in the upper part of Cladonia rangiferina to the reported background or baseline concentrations from other studies. All units are in $\mu \mathrm{g} \mathrm{g}^{-1}$.

\begin{tabular}{|c|c|c|c|c|}
\hline Location & This study & Arctic regions [23] & Norway [24] & Turkey [31] \\
\hline Species & C. rangiferina & Various & C. rangiferina & C. rangiformis \\
\hline Statistics & Mean of the upper part & Min.-Max. & Min.-Max. & Min.-Max. \\
\hline As & 0.300 & $0.06-2.21$ & & \\
\hline $\mathrm{Cd}$ & 0.035 & & $0.03-0.08$ & $0.14-0.69$ \\
\hline $\mathrm{Cr}$ & 0.644 & $0.5-10.2$ & $0.3-0.7$ & $2.24-13.0$ \\
\hline $\mathrm{Cu}$ & 1.803 & $0.7-5.0$ & $0.9-1.0$ & $1.06-5.29$ \\
\hline $\mathrm{Fe}$ & 295.2 & 50-900 & $410-698$ & \\
\hline $\mathrm{Hg}$ & 0.021 & $0.009-0.101$ & $0.02-0.05$ & \\
\hline $\mathrm{Ni}$ & 0.463 & $1.0-5.5$ & $0.4-0.8$ & \\
\hline $\mathrm{Pb}$ & 0.695 & $0.4-9.2$ & $0.6-0.9$ & $1.35-33.8$ \\
\hline $\mathrm{S}$ & 625.9 & $101-961$ & & \\
\hline $\mathrm{Ti}$ & 46.55 & $7-850$ & & \\
\hline $\mathrm{V}$ & 0.784 & $0.17-9.70$ & & \\
\hline $\mathrm{Zn}$ & 18.16 & $6.0-55.0$ & $7.0-11.0$ & $9.15-47.6$ \\
\hline
\end{tabular}

Some researchers have reported that some nutritional elements can translocate to the more biologically active parts of lichen thallus [17]. The vertical patterns of the rest 6 elements in our study might suggest such an internal translocation of these nutrients. The higher accumulations of $\mathrm{B}, \mathrm{Cu}$ and $\mathrm{Mg}$ in lower part (Fig. 2) might suggest a longer exposure to environmental input, but these elements had similar concentrations between the upper and middle parts (Fig. 2), indicating a possible translocation from the middle part to the more metabolically active upper part. This is the case for $\mathrm{Zn}$ in which no pattern was found (Fig. 2). This is also the case for three essential nutrients $(\mathrm{K}, \mathrm{P}$, and $\mathrm{S})$ in which the concentrations were higher in upper part than in middle part (Fig. 2). In addition, concentrations of $\mathrm{K}$ were higher in lower part than in middle part, may also indicating a longer exposure to soil-derived materials because $\mathrm{K}$ is a major element in the earth's crust. These patterns agree with previous studies. For example, 4 nutrients $(\mathrm{Co}$, $\mathrm{Cu}, \mathrm{Mo}$, and $\mathrm{Zn}$ ) were higher in younger part of Flavoparmelia caperata [18]. $\mathrm{K}$ and $\mathrm{Mg}$ were higher in young parts of $F$. caperata and Evernia prunastri [16], but were not significantly different between different parts of Physcia. biziana [20]. The nutrients ( $\mathrm{Zn}, \mathrm{N}, \mathrm{P}, \mathrm{K}, \mathrm{S}$, and $\mathrm{Mg}$ ) were higher at the young parts of Cladonia spp. [14, 15, 26]. These studies attributed such patterns to the internal translocation of nutrients.

Selection of suitable parts of lichen thalli is known to bias the lichen elemental concentration $[3,17]$; the recent studies often used young parts [36, 42]. Our results show that element concentrations are element- and part-specific, highlighting the importance of part selection in lichen biomonitoring studies.

\section{Conclusions}

Element concentrations in Cladonia rangiferina display a very low degree of atmospheric deposition in the region and show element- and part-specific concentrations. Most elements with limited metabolic significance show an increasing concentration from the upper to lower part, suggesting an increasing bioaccumulation with prolonged exposure time. Vertical patterns of some nutrients show an internal translocation from the older parts to younger ones. These results highlight the importance of selection of suitable parts in lichen biomonitoring studies.

\section{Acknowledgments}

The authors would like to thank the National Key Research and Development Program (grant number 2016YFC0500700), the National Natural Science Foundation of China [grant number 31000239], the Natural Science Foundation of Hebei Province (grant numbers C2014201032), the Key Bioengineering Discipline of Hebei Province (grant number 10505030023) and the Key Laboratory of Microbial Diversity Research and Application of Hebei Province for their financial supports. 


\section{Conflict of Interest}

The authors declare no conflict of interest.

\section{References}

1. BRUNIALTI G., FRATI L. Bioaccumulation with lichens: the Italian experience. Int. J. Environ. Stud., 71 (1), 15, 2014.

2. LOPPI S., PAOLI L. May lichen biomonitoring of air pollution serve for the implementation of waste management policies? In Biomonitoring of air pollution using mosses and lichens, a passive and active approach, UROSEVIĆ M.A., VUKOVIĆ G., TOMAŠEVIĆ M., Eds., Nova Publishers: New York, 107, 2017.

3. SHUKLA V., UPRETI D.K., BAJPAI R. Lichens to biomonitor the environment. Springer India: New Delhi, 2014.

4. SUJETOVIENE G. Monitoring lichen as indicators of atmospheric quality, In Recent advances in lichenology, UPRETI D.K., DIVAKAR P.K., SHUKLA V., BAJPAI R., Eds., Springer India: New Delhi, 87, 2015.

5. BARGAGLI R., MIKHAILOVA I. Accumulation of inorganic contaminants, In Monitoring with lichens monitoring lichens, NIMIS P.L., SCHEIDEGGER C., WOLSELEY P.A., Eds., Springer: Dordrecht, 65, 2002.

6. VANNINI A., PAOLI L., NICOLARDI V., DI LELLA L.A., LOPPI S. Seasonal variations in intracellular trace element content and physiological parameters in the lichen Evernia prunastri transplanted to an urban environment. Acta Bot. Croat., 76 (2), 171, 2017.

7. RATIER A., DRON J., REVENKO G., AUSTRUY A., DAUPHIN C.-E., CHASPOUL F., WAFO E. Characterization of atmospheric emission sources in lichen from metal and organic contaminant patterns. Environ. Sci. Pollut. Res., 25 (9), 8364, 2018.

8. SENHOU A., CHOUAK A., CHERKAOUI R., MOUTIA Z., LFERDE M., ELYAHYAOUI A., KHOUKHI T.E., BOUNAKHLA M., EMBARCHE K., GAUDRY A., AGRAULT S., MOUSKURA M. Sensitivity of biomonitors and local variations of element concentrations in air pollution biomonitoring. J. Radioanal. Nucl. Chem., 254 (2), 343, 2002.

9. ZHAO L.L., ZHANG C., JIA S.J., LIU Q.X., CHEN Q.Z., LI X., LIU X.D., WU Q.F., ZHAO L.C., LIU H.J. Element bioaccumulation in lichens transplanted along two roads: The source and integration time of elements. Ecol. Indic., 99, 101, 2019.

10. INCERTI G., CECCONI E., CAPOZZI F., ADAMO P., BARGAGLI R., BENESPERI R., CARNIEL F.C., CRISTOFOLINI F., GIORDANO S., PUNTILLO D., SPAGNUOLO V., TRETIACH M. Infraspecific variability in baseline element composition of the epiphytic lichen Pseudevernia furfuracea in remote areas: implications for biomonitoring of air pollution. Environ. Sci. Pollut. Res., 24 (9), 8004, 2017.

11. PURVIS O.W., WILLIAMSON B.J., BARTOK K., ZOLTANI N. Bioaccumulation of lead by the lichen Acarospora smaragdula from smelter emissions. New Phytol., 147 (3), 591, 2000.

12. PURVIS O.W., BENNETT J.P., SPRATT J. Copper localization, elemental content, and thallus colour in the copper hyperaccumulator lichen Lecanora sierrae from California. Lichenologist, 43 (2), 165, 2011.
13. GODINHO R.M., WOLTERBEEK H.T., PINHEIRO M.T., ALVES L.C., VERBURG T.G., FREITAS M.C. Microscale elemental distribution in the thallus of Flavoparmelia caperata transplanted to polluted site. J. Radioanal. Nucl. Chem., 281 (2), 205, 2009.

14. PAKARINEN P. Nutrient and trace metal content and retention in reindeer lichen carpets of Finnish ombrotrophic bogs. Ann. Bot. Fenn., 18 (4), 265, 1981.

15. PAKARINEN P. Mineral element accumulation in bog lichens, In Lichen physiology and cell biology, BROWN D.H., Ed., Springer: Boston, MA, 185, 1985.

16. GODINHO R.M., VERBURG T.G., FREITAS M.C., WOLTERBEEK H.T. Accumulation of trace elements in the peripheral and central parts of two species of epiphytic lichens transplanted to a polluted site in Portugal. Environ. Pollut., 157 (1), 102, 2009.

17. BAČKOR M., LOPPI S. Interactions of lichens with heavy metals. Biol. Plantarum, 53 (2), 214, 2009.

18. LOPPI S., NELLI L., ANCORA S., BARGAGLI R. Accumulation of trace elements in the peripheral and central parts of a foliose lichen thallus. Bryologist, 100, 251, 1997.

19. CECCONI E., FORTUNA L., BENESPERI R., BIANCHI E., BRUNIALTI G., CONTARDO T., DI NUZZO L., FRATI L., MONACI F., MUNZI S. New interpretative scales for lichen bioaccumulation data: the Italian proposal. Atmosphere, 10 (3), 136, 2019.

20. CATALANO I., SANTITORO A., MINGO A., BALDANTONI D., ALFANI A., APRILE G.G. Different effects of rain and artificial watering on element zonation patterns in lichen thalli and bark: A study on Physcia biziana (Massal.) Zahlbr. v. leptophylla Veùzda. Plant Biosyst., 150 (3), 564, 2016.

21. PAKARINEN P., MÄKINEN A., RINNE R.J.K. Heavy metals in Cladonia arbuscula and Cladonia mitis in eastern Fennoscandia. Ann. Bot. Fenn., 15 (4), 281, 1978.

22. OSYCZKA P., ROLA K., JANKOWSKA K. Vertical concentration gradients of heavy metals in Cladonia lichens across different parts of thalli. Ecol. Indic., 61, 766, 2015.

23. NASH T.H., III, GRIES C. The use of lichens in atmospheric deposition studies with an emphasis on the Arctic. Sci. Total Environ., 160/161, 729, 1995.

24. WOJTUŃ B., SAMECKA-CYMERMAN A., KOLON K., KEMPERS A., SKRZYPEK G. Metals in some dominant vascular plants, mosses, lichens, algae, and the biological soil crust in various types of terrestrial tundra, SW Spitsbergen, Norway. Polar. Biol., 36, 1799, 2013.

25. POPOVA E., Accumulation of heavy metals with the lichen thalli of Cladonia rangiferina L. at the roadside phytocenoses of the West Siberian Subarctic. IOP Conf. Ser.: Earth Environ. Sci., IOP Publishing, 012045, 2019.

26. BYAZROV L., PEL L. Composition and ratio of the chemical elements on the surfaces different by height of reideer lichen podetia Cladonia rangiferina. Principy Ekologii, 5 (2), 27, 2016.

27. SHEVCHENKO V., POKROVSKY O., STARODYMOVA D., VASYUKOVA E., LISITZIN A., DROVNINA S., ZAMBER N., MAKHNOVICH N., SAVVICHEV A., SONKE J., Geochemistry of terricolous lichens in the White Sea catchment area. Dokl. Earth Sci., 450 (1), 514, 2013.

28. SUEOKA Y., SAKAKIBARA M., SANO S., YAMAMOTO Y. A new method of environmental assessment and monitoring of $\mathrm{Cu}, \mathrm{Zn}, \mathrm{As}$, and $\mathrm{Pb}$ 
pollution in surface soil using terricolous fruticose lichens. Environments, 3 (4), 35, 2016.

29. WIDORY D., VAUTOUR G., POIRIER A. Atmospheric dispersion of trace metals between two smelters: An approach coupling lead, strontium and osmium isotopes from bioindicators. Ecol. Indic., 84, 497, 2018.

30. HARMENS H., Heavy metals in European mosses: 2010 survey. Monitoring manual. Available on line http:// nora.nerc.ac.uk/id/eprint/9952/1/UNECEHEAVYMET A L S M O S S M A N UA L 2010 P OPs a d a p te d f i nal_220510_.pdf, 2009.

31. CAYIR A., COSKUN M., COSKUN M. Determination of atmospheric heavy metal pollution in Canakkale and Balikesir Provinces using lichen (Cladonia rangiformis) as a bioindicator. Bull. Environ. Contam. Toxicol., 79 (4), 367, 2007.

32. ADAMS M.D., GOTTARDO C. Measuring lichen specimen characteristics to reduce relative local uncertainties for trace element biomonitoring. Atmos. Pollut. Res., 3 (3), 325, 2012.

33. AGNAN Y., PROBST A., SÉJALON-DELMAS N. Evaluation of lichen species resistance to atmospheric metal pollution by coupling diversity and bioaccumulation approaches: A new bioindication scale for French forested areas. Ecol. Indic., 72, 99, 2017.

34. SINGH S.M., SHARMA J., GAWAS-SAKHALKAR P., UPADHYAY A.K., NAIK S., PEDNEKER S.M., RAVINDRA R. Atmospheric deposition studies of heavy metals in Arctic by comparative analysis of lichens and cryoconite. Environ. Monit. Assess., 185 (2), 1367, 2013.

35. MONACI F., FANTOZZI F., FIGUEROA R., PARRA O., BARGAGLI R. Baseline element composition of foliose and fruticose lichens along the steep climatic gradient of SW Patagonia (Aisén Region, Chile). J. Environ. Monitor., 14 (9), 2309, 2012.

36. NANNONI F., SANTOLINI R., PROTANO G. Heavy element accumulation in Evernia prunastri lichen transplants around a municipal solid waste landfill in central Italy. Waste Manage., 43, 353, 2015.
37. LUCADAMO L., CORAPI A., LOPPI S., DE ROSA R., BARCA D., VESPASIANO G., GALLO L. Spatial variation in the accumulation of elements in thalli of the lichen Pseudevernia furfuracea (L.) Zopf transplanted around a biomass power plant in Italy. Arch. Environ. Contam. Toxicol., 70 (3), 506, 2016.

38. LUCADAMO L., CORAPI A., GALLO L. Evaluation of glyphosate drift and anthropogenic atmospheric trace elements contamination by means of lichen transplants in a southern Italian agricultural district. Air Qual. Atmos. Health, 11 (3), 325, 2018.

39. CECCONI E., INCERTI G., CAPOZZI F., ADAMO P., BARGAGLI R., BENESPERI R., CARNIEL F.C., FAVERO-LONGO S.E., GIORDANO S., PUNTILLO D., RAVERA S., SPAGNUOLO V., TRETIACH M. Background element content of the lichen Pseudevernia furfuracea: A supra-national state of art implemented by novel field data from Italy. Sci. Total Environ., 622/623, 282, 2018.

40. BARRE J.P., DELETRAZ G., FRAYRET J., PINALY H., DONARD O.F., AMOUROUX D. Approach to spatialize local to long-range atmospheric metal input $(\mathrm{Cd}, \mathrm{Cu}, \mathrm{Hg}$, $\mathrm{Pb}$ ) in epiphytic lichens over a meso-scale area (PyrénéesAtlantiques, southwestern France). Environ. Sci. Pollut. Res., 22 (11), 8536, 2015.

41. JIA S.J., ZHANG X., LIU Q.X., CHEN Q.Z., LI X., PANG X.M., LI J.J., WU Q.F., ZHAO L.C., LIU H.J. Spatial-temporal patterns of element concentrations in Xanthoparmelia camtschadalis transplanted along roads. Pol. J. Environ. Stud., 29 (1), 121, 2020.

42. LIU H.J., FANG S.B., LIU S.W., ZHAO L.C., GUO X.P., JIANG Y.J., HU J.S., LIU X.D., XIA Y., WANG Y.D., WU Q.F. Lichen elemental composition distinguishes anthropogenic emissions from dust storm input and differs among species: Evidence from Xilinhot, Inner Mongolia, China. Sci. Rep.-UK., 6, 34694, 2016. 